The Canadian Mineralogist

Vol. 38, pp. 1163-1175 (2000)

\title{
P-T PATH AND FLUID EVOLUTION IN THE FRANQUEIRA GRANITIC PEGMATITE, CENTRAL GALICIA, NORTHWESTERN SPAIN
}

\author{
MERCEDES FUERTES-FUENTE
}

Departamento de Geología, Universidad de Oviedo, Arias de Velasco sth, E-33005 Oviedo, Spain

MARIE CHRISTINE BOIRON

CREGU-UMR G2R, BP 23, F-54501 Vordeunre-1es-Nancy Cedex, France

\section{JOSE MANGAS VINUUELA}

Departamento de Geologla, Universidad de Las Palmas de G.C. Apdo. 550, E-35080 Las Palmas, Spain

\section{ABSTRACT}

In Galicin, in the northwestern part of the lberian Peninsula, there are reveral occurrences of granitic pegmatites. One of them, known as Franqueira, is a metzsomatic deposit of gem-quality chrysoberyl, emerald and phenskite. The pegmatite is associated with a two-mica peraluminous Hercynien granite, and intrude dunites of the Schistose domain in the Galicien Tras-Os-Montes Zone. The composition of fluid inclusions in emerald and phenshite has been determined using a Raman microprobe to ascertain the paleofluid chemistry and the P-T conditions of fluid mignation in the pegmatite. Three types of fluid inclusions bave been identified in emerald and phenskite; three episodes of fluid circulation are distinguished. The first episode is represented by lowsalinity aqueous-carbonic primary fluid inclusions in phenakite; these were trapped at $2.5 \mathrm{kbar}$ and $400^{\circ} \mathrm{C}$. An isothermal drop in pressure produced a second stage of fluid trapping under conditions of $400^{\circ} \mathrm{C}$ and $1 \mathrm{lbar}$. Fluid inclusions trapped in emerald indicate that during this second stage, it formed from phenakite and chrysoberyl in the presence of a $\mathrm{CO}_{2}$ - and $\mathrm{CH}_{2}$-rich fluid. A third episode of fluid circulation suggests an independent stage of fluid circulation during late tectonic events, with temperatures ranging from $160^{\circ}$ to $265^{\circ} \mathrm{C}$ and pressure below 0.5 kbar.

Keywords: granitic pegmatite, fluid inclusion, microthermometry, Raman microprobe, P-T path, fluid evolution, Franqueira, Galicia, Spain.

\section{SOMMAIRE}

En Galice, dans le secteur nord-ouest de la Peninsule Iberique, on trouve plusieurs massifs de pegmatites grenitiques. Un de ceux-ci, Franqueira, est le site d'un gisement metasomatique de chrysoberyl, Emeraude ex phénekite gemmes. La pegmatite est associte a un massif hereynien de granite hyperalumineux a deux micas, mis en place dans des dunites du domaine de schistes de la zone Tras-Os-Montes. La composition des inclusions fluides dans l'emeraude et la phínakite a tte trablie au moyea d'une microsonde Raman afin de determiner la composition du palbofluide et des conditions de pression et de temperature au cours de sa migration dans la pegmatite. Nous avons identifit trois types d'inclusions fluides dans l'emeraude et la phtnakite, qui témoignent de trois épisodes de circulation d'une phase fluide. Le premier a doané des inclusions primaires aqueuses et primaires dans la phénakite, piégées $\$ 2.5$ kbar et $400^{\circ} \mathrm{C}$. Une chute isotherme de la pression a produit un second stade de piégeage, i $400^{\circ} \mathrm{C}$ et $1 \mathrm{kbar}$. Les inclusions associces 1 ce deuxieme épisode piegetes dans l'emeraude indiquent un mode de sa formation par remplacement aux dépens de la phénakite et du chrysobetryl par une phase fluide riche en gaz carbonique et en méthane. Un troisième épisode de circulation serait indépendant des deux premiers, développé au cours d'une deformation tardive à une temptrature allant de $160^{\circ} \& 265^{\circ} \mathrm{C}$ et une pression inferieure d $0.5 \mathrm{kbar}$.

(Traduit par la Redaction)

Mots-cles: pegmatite granitique, inclusions fluides, microthermometrie, microsonde Raman, track de pression et de temperature, évolution de la phase fluide, Franqueira, Galice, Espagne.

1 E-mail address: mercedf@asturias.geol.uniovi.es 


\section{INTRODUCTION}

There are several occurrences of rare-element-enriched granitic pegmatite in the central part of Galicia, in the northwestern region of the Iberian Peninsula. One of these, Franqueira, is a well-documented example of 2 deposit of gem-quality chrysoberyl, emerald and phenakite in western Europe (Martin-Izard et al. 1995). The geological conditions of formation of the Franqueira deposit have led Martin-Izard et al. (1995) to include it in the suture-zone group (Snee \& Kazmi 1989) or in the type-I deposit, the Ural Mountains type, in the classification of Giuliani et al. (1997), on the basis of exometasomatic phenomena (Fersman 1929, Sinkankas 1989, Guliani et al. 1997). The deposit showing the closest similarity to Franqueira in its mineralogical association, geological environment and age of formation (Paleozoic), is Tokovaja, in the Ural Mountains, Russia (Sinkankas 1989, Laznicka 1985, Giuliani et al. 1997).

The purpose of this paper is to present the results of a combined Raman microprobe and fluid-inclusion study carried out on emerald and phenakite from the Franqueira deposit, located in the central part of Galicia, in the northwestern Iberian Peninsula. Results of these studies allow us to determine the evolution of fluids and the $\mathrm{P}-\mathrm{T}-\mathrm{V}-\mathrm{X}$ conditions of the multistage circulation of fluids in the metasomatic zone around the pegmatite and also to establish the conditions of formation of the beryllium-bearing gems.
The origins of the fluids involved and the possible interaction between the pegmatite-derived fluids and those derived from the host rock also are discussed. From these results, a fluid immiscibility in the system $\mathrm{H}_{2} \mathrm{O}-\mathrm{CH}_{1}-\mathrm{CO}_{2}-\mathrm{NaCl}$ likely contributed to the evolution of the fluid in the case of Be-rich pegmatites that metasomatized adjacent ultramafic rocks.

\section{The Franouetra Derost}

The Franqueira pegmatite is located in the northwestem part of the Iberian Peninsula, in the Galician TrasOs-Montes Zone (Matte 1968, Farias et al. 1987, Martinez Catalín et al. 1996) (Fig. 1). The Tras-OsMontes Zone consists of two domains: (1) schistose rocks, including mafic-ultramafic overthrusted complexes (Cambrian to Silurian in age), and (2) granitic rocks, including two-mica peraluminous synkinematic granitic rocks (330-310 Ma, Priem \& Den Tex 1984, Serrano Pinto et al. 1987, Van Calsteren et al. 1979). The former is composed of metamorphic rocks and the Lalin-Forcarei Unit, the southern end of the large Ordenes Complex (Barrera et al. 1989, Monterrubio 1991). The Ordenes Complex, as well as the LalinForcarei Unit, which overthrusts the other groups of the schist domain during D1 and D2 Hercynian deformation events (360-330 Ma, Dallmeyer et al. 1997), consists of gabbro, amphibolite, orthogneiss, dunite and other ultramafic rocks (Monterrubio 1991). The regional

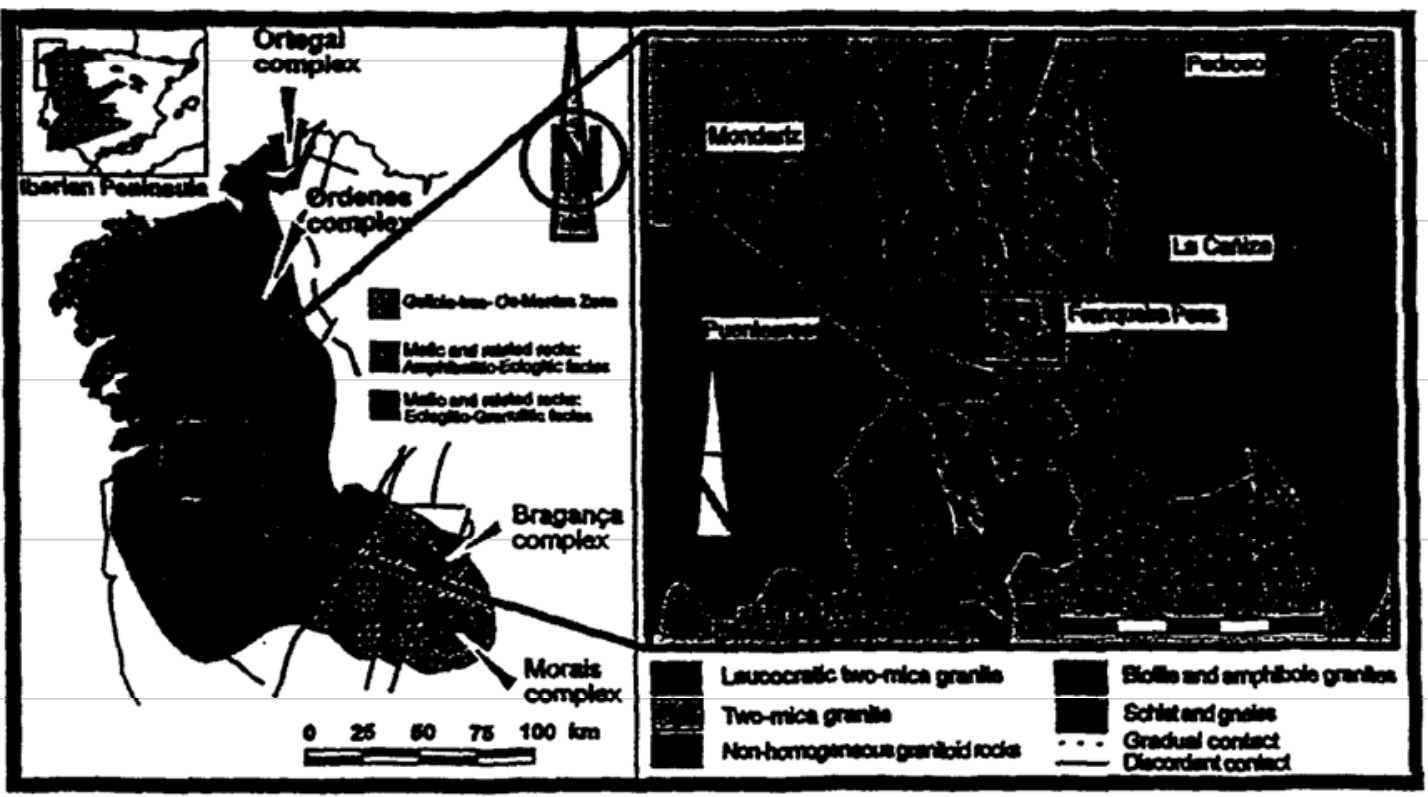

Fic. 1. Setting and schematic geological map of the Franqueira deposit, adapted from Barrera et al. (1989). 
geological setting of the Franqueira pegmatite was outlined by Martin-Izard et al. (1995, 1996).

The Franqueira deposit occurs between ophiolite complexes of Galicia (Ordenes Complex) and Portugal (Braganca and Morais complexes). These complexes represent fragments of oceanic crust that were thrust over the schist of the schistose domain during the first and second phase of the Hercynian Orogeny. Heterogeneous two-mica granite (Barrera ef al. 1989) were emplaced during the third tectonic phase ( $315 \pm 10 \mathrm{Ma}$ : Capdevila \& Vialette 1970). At Franqueira, the pegmatite bodies, related to the heterogeneous two-mica granites, cross-cut an ultramafic rock of dunitic character and associated gabbroic roclos.

Martin-Izard et al. (1995) suggested that the dunite and hornblende gabbro considered here belong to a remnant of peridotitic and gabbroic rocks from the overthrusted complexes. This suggestion is supported by the fact that the geochemical and mineralogical characteristics of Franqueire dunite and gabbro are similar to those of the the Ordenes, Bragança and Morais complexes.

Later, during the intrusion of the Hercynian granites, the dunite and hornblende gabbro could have remained in the roof zone of the peraluminous heterogeneous twomica granites, which normally have a suite of associated pegmatite bodies. The Franqueira pegmatite, which is enriched in Be, B and $\mathrm{P}$, caused metasomatic alteration of the adjacent dunite, with formation of phlogopitite near the pegmatite, and tremolitite bodies and an anthophyllite rim close to the dunite. The $\mathrm{Mg}$ and $\mathrm{Cr}$ of these rocks were provided by the dunite. The addition of boron and phosphorus resulted in the formation of tourmaline and abundant apatite in the metasomatic facies, along with phlogopite. In the zones closest to the pegmatite, the Be spread out in the system and first developed chrysoberyl ("alexandrite") and phena- kite porphyroblasts, isolated or intergrown in the phlogopitite.

The bodies of granitic pegmatites form a network of narrow, anastomosing subvertical dikes that trend approximately east-west. The dike system (Fig. 2) is exposed for 15-20 meters. Dike thickness ranges from 3 to $40 \mathrm{~cm}$. Relies of dunite totally transformed to phlogopite are commonly found within the pegmatite.

The pegmatite bodies show a simple zonation with an aplitic border. Essential minerals are quartz, albite, muscovite and scarce K-feldspar, with apatite, tourmaline and zircon as accessory minerals. In the main zone of the pegmatite, albite is the most abundant mineral, with quart in lesser proportion and some muscovite. Within the pegmatitic bodies of greater thickness, a banding can be observed in the central zone, in which a coarse-grained rock alternates with another of saccharoidal appearance. In the coarse-grained facies, there are crystals of coarse bladed albite with subhedral albite, interstitial euhedral quartz, and muscovite plates. In the saccharoidal facies, garnet and tourmaline abound.

The host rocks have a clearly defined contact with the pegmatites and are of a micaceous nature. The mica is phlogopite, and is the most abundant mineral (over $75 \%$, up to $90 \%$ ) in this facies (Fig. 2). The visible thickness of this rock is up to three meters, and it crops out for at least five meters. The accessory minerals are chrysoberyl ("alexandrite"), phenakite, beryl ("emerald"), tourmaline, garnet (mainly almandine), apatite (fluorapatite, $3.5 \mathrm{wt} \% \mathrm{~F}$ ) and zircon.

Chrysoberyl [Fig. 3A(C)] appears as subhedral porphyroblasts isolated in the phlogopite or as skeletal intergrowths within emerald, phenakite and apatite. Phenakite [Figs. 3A(P), 3B] appears as subhedral and coloriess prismatic crystals up to $3 \mathrm{~cm}$ in size. Phenakite commonly has associated apatite crystals [Fig. 3A(A)]. Beryl appears as euhedral prismatic crystals with sizes

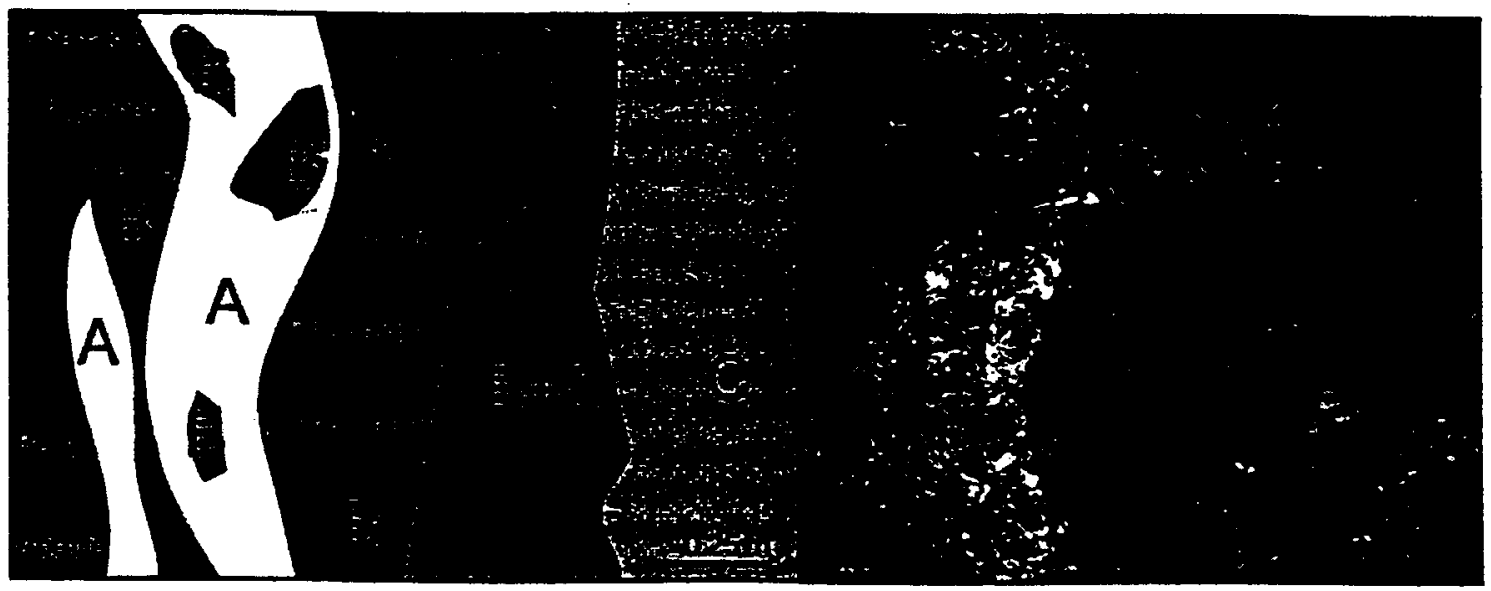

Fio. 2. View of the pegmatite dikes, which are lenticular (A). The pegmatite is hosted by phlogopitite (B) and tremolitite (C). 
of up to $30 \mathrm{~cm}$ [Figs. 3A(B), 3B]; an intense green color and $\mathrm{C} \tau$ content (up to $0.2 \mathrm{wt} \%$ ) give it its emerald-like character. It is the latest $B e$ mineral and replaces the chrysoberyl and phenakite (Fig. 3A). Tourmaline (dravite) is developed at the contact between phlogopitite and the pegmatite.

Beryl porphyroblasts developed and partially replaced the other two Be minerals owing to the increasing activity of $\mathrm{H}_{4} \mathrm{SiO}_{4}$ (at constant temperature) in accordance with the reaction:

$$
\begin{aligned}
& \text { chrysoberyl }+ \text { phenakite }+5 \mathrm{H}_{4} \mathrm{SiO}_{4} \\
& =\text { beryl }+10 \mathrm{H}_{2} \mathrm{O}
\end{aligned}
$$

proposed by Barton (1986). Invariably, where chrysoberyl and phenakite are together, they are replaced by beryl (emerald) and appear as a skeletal intergrown within the emerald.

The phlogopitite grades into a tremolitite in which pockets of phlogopite are ubiquitous (Fig. 2). The visible thickness of this rock is up to six meters. In the tremolitite, the rock is essentially composed of tremo-
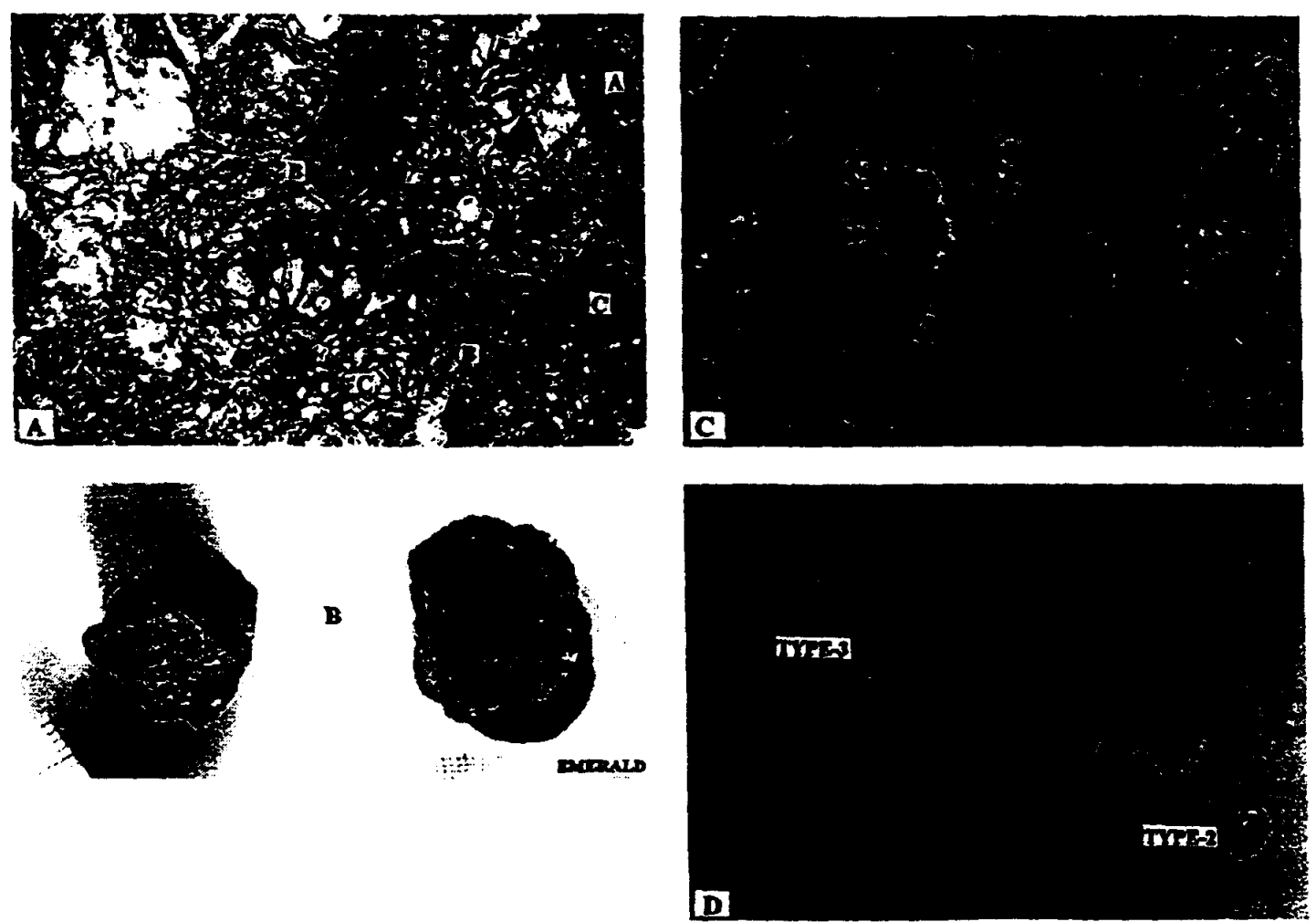

FIG. 3. A. Microscopic view of chrysoberyl (C), phenakite (P), beryl (B), and apatite (A). Phenakite and skeletal corroded crystals of chrysoberyl are included in emerald. XPL, 10X. B. Emerald and phenakite crystals used for the study of fluid inclusions. C. Primary complex $\mathrm{CH}_{4}$ aqueous inclusions (type-1) in emerald crystals. XPL, 45X. D: Primary complex $\mathrm{CO}_{2}$ aqueous inclusions (type-2) and secondary saline aquecus inclusions (type-3) in emerald crystals. XPL, 45X. 
Las Palmas (Spain). The stage was calibrated according to the procedures outlined by Poty et al. (1976). The detailed analytical techniques of the microthermometric study are described in Martin-Izard et al (1995).

The composition of the non-aqueous portion of individual inclusions was measured using a Dilor $X-Y$ multichannel modular Raman spectrometer (u CREGU). Bulk composition and density were computed from the $P-V-T-X$ properties of individual inclusions in the $C$ O-H-N-S) system (Dubessy 1984, Dubessy et al. 1989, 1992, Thiety et al. 1994, Bakker 1995). All data were calculated from the microthermometric measurements and the $R$ mmm analyces of the gas, using a clathrate stability model in the system $\mathrm{H}_{2} \mathrm{O}-\mathrm{CH}_{4}-\mathrm{N}_{2}-\mathrm{NaCl}$ $\mathrm{KCl}-\mathrm{CaCl}_{2}$, between 253 and $293 \mathrm{~K}$ and between 0 and $200 \mathrm{MPa}$ (Bakker 1995, Bakker et al. 1996) and the computer program of Balder (1997).

The $\mathrm{P}-\mathrm{V}-\mathrm{T}-\mathrm{X}$ properties of aqueous carbonic inclusions were modeled in terms of the system $\mathrm{H}_{2} \mathrm{O}-\mathrm{CO}_{2}-$ $\mathrm{CH}_{4}$ using the state equations of Kerrick \& Jacobs (1981) and Jacobs \& Kerrick (1981) and the computer code of Dubessy (1984). Only in one case (type-1 inclusions in phenskite) did we use the equation of state of Bowers \& Helgeson (1983). For aqueous inclusions, the isochores have been drawn in the $\mathrm{H}_{2} \mathrm{O}-\mathrm{NaCl}$ system using the data from Zhang \& Frant (1987) and the computer program Macflincor 0.92 (Brown \& Hagemann 1995).

\section{Selectang Samples, Incuusion Types AND MICROTFIERMOMETRIC RESULTS}

In the Franqueira deposit, samples of emerald and phenakite (Fig. 3B) have been taken from the metasomatic phlogopite-rich zone (Martin-Izard et al 1995). Both minerals have the potential to provide information on the conditions of metasomatism around the pegmatite. Fluids inclusions in chrysoberyl are scarce and are too small (less than $1 \mathrm{\mu m}$ ) for study.

Observations show that emerald and phenakite have a significant number of inchusions, isolated or in groups; these are interpreted as primary (Figs. 3C, D). Other inclusions related to fractures are classified as pseudosecondary or secondary on the basis of the criteria of Roedder (1984) (Fig. 3D). Inclusion morphology is equally variable, being roundish, elongate, tubular, subhedral negative crystal or irregular. The size of the inclusions studied ranges from 5 to $60 \mu \mathrm{m}$ in size (Figs. 3C, D).

One hundred and twenty-five fluid inclusions were selected and studied by microthermometry in the two minerals. In all emerald and phenakite crystals studied (more than 10), fluid inclusions have the same morphological characteristics and volumetric ratios.

The fluid-inclusion studies of the Franqueira deposit reported by Martin-lzard et al. (1995) indicate the presence of three types of inclusions. Type 1 consists of complex $\mathrm{CH}_{4}$-bearing aqueous inclusions (Fig. $3 \mathrm{C}$ ).
These show two phases at room temperature. The vapor phase cocupies between 20 and $50 \%$ of the total volume of the inclusions. We consider these inclusions to be primary or pseudosecondary, and they are the most representative of emerald and phenakite.

After cooling and subsequent heating, the $\mathrm{CH}_{4}$ liquid and vapor phases homogenized to either the vapor (V) or liquid (L) state or critical (C) stage. This occurs at temperatures ranging from -83 to $-106^{\circ} \mathrm{C}$ into $\mathrm{V}$ and from -82 to $-90^{\circ} \mathrm{C}$ into $\mathrm{L}$ phases in the emerald, and from -86 to $-106^{\circ} \mathrm{C}$ into $\mathrm{V},-88.5$ to $-110.5^{\circ} \mathrm{C}$ into $\mathrm{L}$, and -86.5 and $-89^{\circ} \mathrm{C}$ into $\mathrm{C}$ phases in the phenalite.

The temperature of initial ice melting, where meaarrable, wns found to be mostly around the stable entectic for the $\mathrm{NaCl}-\mathrm{H}_{2} \mathrm{O}$ system, $-20.8^{\circ} \mathrm{C}$ (Potter \& Brown 1977). Although the use of wt\% equivalent $\mathrm{NaCl}$ in such inclusions seems insppropriate, the overestimated salinity based on the final temperature of ice melting, with reference to the $\mathrm{H}_{2} \mathrm{O}-\mathrm{NaCl}$ system (Potter et al. 1978), ranges between 5 and 8 wt\% equivalent $\mathrm{NaCl}$.

Total bomogenization temperatures range between $318^{\circ}$ and $369^{\circ} \mathrm{C}$ in the liquid state and between $354^{\circ}$ and $373^{\circ} \mathrm{C}$ in the vapor state. Some of the measured inclusions decrepitated before total homogenization was achieved.

Type-2 inclusions are complex $\mathrm{CO}_{2}$-bearing aqueous inclusions (Fig. 3D). These inclusions contain two phases at room temperature and show volumetric proportions $\mathrm{Vg} / \mathrm{Vt}$ (vapor volume/total volume) below $50 \%$. The inclusions appear only in the core of emerald crystals and have the same distribution as the type-1 inclusions, but are less abundant. Martin-Izard et al (1995) considered these inclusions as primary or pseudosecondary and contemporaneous with type-1 inclusions. During cooling, the two-phase inclusions in some cases transform into three-phase inclusions $\left(\mathrm{H}_{2} \mathrm{O}\right.$ $\mathrm{L}+\mathrm{CO}_{2} \mathrm{~V}+\mathrm{CO}_{2} \mathrm{~L}$ ). The melting of solid $\mathrm{CO}_{2}$ has been measured at between $-60.8^{\circ}$ and $-62.1^{\circ} \mathrm{C}$. Salinities were overestimated approximately from the final melting of ice values and the formulae proposed by Potter et al. (1978) for the system $\mathrm{H}_{2} \mathrm{O}-\mathrm{NaCl}$, and ranged from 5 to $10.5 \mathrm{wt} \%$ equivalent $\mathrm{NaCl}$.

Most of the total homogenization in the liquid state occurs between $320^{\circ}$ and $378^{\circ} \mathrm{C}$; only two inclusions homogenized into the gas and critical state at $381^{\circ} \mathrm{C}$. This degree of variability in pattern of homogenization can be explained by small differences in the bulk composition of the fluid.

Type-3 inclusions are mixed-salt aqueous inclusions. These show two phases at room temperature in which the vapor bubble occupies less than 10\% (Fig. 3D). These inclusions occur in both emerald and phenakite and are relatively scarce. The inclusions are secondary in character. Temperatures of first melting of ice vary between $-45^{\circ}$ and $-55^{\circ} \mathrm{C}$; these temperatures are lower than the eutectic temperature of the $\mathrm{H}_{2} \mathrm{O}-\mathrm{NaCl}$ system (Potter \& Brown 1977). The temperature of final melt- 
ing of ice ranges between -2.1 and $-23^{\circ} \mathrm{C}$. Taking into account these temperatures and the experimental data of Potter et al (1978) for the system $\mathrm{H}_{2} \mathrm{O}-\mathrm{NaCl}$, the salinity ranges betwreen 3.5 and $24.7 \mathrm{wt} \%$ equivalent $\mathrm{NaCl}$. Homogenization temperatures range between $160^{\circ}$ and $265^{\circ} \mathrm{C}$ in the liquid state.

The microthermometric messurements of MartinIrand et al. (1995) are summarized in Table 1.

Clearty, frem the above microthermometric data, no great differences exist between the fluid inclusion populations of emerald and phenskite; two discontinuous hydrothermal stages con be distinguished. The first hydrothermal stage was chancterized by the circulation and trapping of aqueous fluid with some volatiles of typo-1 and -2 inclusions (complex $\mathrm{CH}_{-}-\mathrm{CO}_{2}$ aqueous inchusions), with alinities below $10 \mathrm{wt} \%$ equivalent $\mathrm{NaCl}$ and a low density of bubbles. This fluid circulated at minimum temperatures of between $318^{\circ}$ and $3811^{\circ} \mathrm{C}$, and the lithostatic or hydrostatic pressure was high enough to prevent boiling.

The characteristics of type-3 inclusions, showing a secondary character, lower temperatures of homogenization, lacking $\mathrm{CH}_{4}, \mathrm{CO}_{2}$ and other volatiles, having a variable salinity, and with solutions containing several cations, suggest an independent episode of hydrothermal fluid circulation during the later tectonic events. Thus, the second hydrothermal stage corresponds to the circulation and trapping of aqueous solutions of salinity below 24.7 wt\% equivalent $\mathrm{NaCl}$, containing cations such as $\mathrm{Ca}, \mathrm{Mg}, \mathrm{K}$ and $\mathrm{Na}$, among others, with densities ranging 0.9 to $1.15 \mathrm{~g} / \mathrm{cm}^{3}$, at minimum trapping temperatures ranging 160 and $265^{\circ} \mathrm{C}$.

\section{Raman Data}

Raman microprobe analyses were carried out on type-1 (in phenakite and in emerald) and type-2 inclusions from Franqueira. From Raman analyses and microthermometric data, the density and composition of the volatile-rich phase together with the bulk density and composition were calculated. In onder to obtain these data, the above-mentioned clathrate stability model was applied, but in the case of type-1 phenakite inclusion, results could not be obtained because the clathrate melting temperature $\left(>20^{\circ} \mathrm{C}\right)$ is above the limits of stability of the model (between 253 and $293 \mathrm{~K}$ ) and, moreover, there is a large difference between ice and clathrate melting temperatures. Nevertheless, it was possible to obtain a solution if we assumed that there was no salt in ine system. This hypothesis is probably a reasconable extimate because the measured final ice melting temperature in these inclusions is low $\left(-4^{\circ} \mathrm{C}\right)$, thus salinity is close to 6 wt.\% equivalent $\mathrm{NaCl}$. This value is low and, in any case, overestimated owing to the fact that the clathrate is present when the ice melts. On the basis of these facts, we assumed that there is no salt in the fluid trapped by phenakite.

All data are shown in Table 2. Raman microprobe analyses show thet type-1 inclusions in emerald have a different density and composition of the volatile-rich phase than type-1 inclusions in phenakite.

$\mathrm{H}_{2} \mathrm{O}$ is the main component of the fluid phase in type-1 inchusions trapped in emerald and phenakite. The volatile-rich phase of inclusions in both minerals is dominated by $\mathrm{CH}_{4}$. In the case of type-1 inclusions trapped in phenakite, $\mathrm{N}_{2}$ is present in higher quantities than in type-1 inclusions trapped in emerald; moreover, the type-1 fluid in emerald also contains $\mathrm{CO}_{2}$. The composition of the volatile phase of type-1 inclusions in phenakite is 80.5 to 85.2 mole \% CH4 and 14.8 to 19.5 mole $\% \mathrm{~N}_{2}$. The composition of the volatile phase in type-1 inclusions in emerald is 78.9 to 80 mole $\% \mathrm{CH}_{4}$, 2.5 to 15.7 mole $\% \mathrm{CO}_{2}$ and 5.4 to 7.5 mole $\% \mathrm{~N}_{2}$.

Type- 2 inclusions have also an aqueous composition and their volatile-rich phase is dominated by $\mathrm{CO}_{2}$ and minor quantities of $\mathrm{CH}_{4}$ and $\mathrm{N}_{2}$. The volatile phase composition of type-2 inclusions is 52 to 68 mole $\% \mathrm{CO}_{2}$, 19.5 to 41.2 mole $\% \mathrm{CH}_{4}$ and 6.7 to 12.5 mole $\% \mathrm{~N}_{2}$.

TABLE 1. SUMAMAY OF TER MICROTHERMOMETRIC DATA FOR TEE DFFERENT TYPES OF FLUD DNCLUSIONS IN TEE FRANOUERA DEPOST

\begin{tabular}{|c|c|c|c|c|c|c|c|c|c|}
\hline Types & host-mineral & $\mathbf{N}$ & $\mathrm{T}=\mathrm{CO}_{2}$ & $\mathrm{ThCO}_{2}$ & & $\mathrm{TCF}_{4}$ & Trinel & Trice & $\mathbf{T h}$ \\
\hline $\begin{array}{l}\text { Type-1 } \\
\text { Type-2 } \\
\text { Type-3 }\end{array}$ & $\begin{array}{l}\text { emereld } \\
\text { exonld } \\
\text { emenild }\end{array}$ & $\begin{array}{c}39 \\
31 \\
7\end{array}$ & $\begin{array}{c}-60.8+62.1 \\
-\end{array}$ & $-11.21010 \mathrm{G}$ & $\begin{array}{l}-82 \\
-83\end{array}$ & $\begin{array}{l}\text { to }-90 \mathrm{~L} \\
\text { to }-106 \mathrm{G} \\
- \\
-\end{array}$ & $\begin{array}{c}115 \text { to } 19 \\
119 \text { to } 22 \\
=\end{array}$ & $\begin{array}{l}-35 \text { to }-5.2 \\
-310-7 \\
-1310-23\end{array}$ & $\begin{array}{c}318 \text { 10 } 369 \mathrm{~L} \\
354 \mathrm{G} \\
32010378 \mathrm{~L} \\
381 \mathrm{G} \\
381 \mathrm{C} \\
160 \text { t0 } 245 \mathrm{~L}\end{array}$ \\
\hline $\begin{array}{l}\text { Typo-1 } \\
\text { Type-3 }\end{array}$ & $\begin{array}{l}\text { phenabite } \\
\text { phemabite }\end{array}$ & $\begin{array}{l}40 \\
8\end{array}$ & - & - & $\begin{array}{l}-8 . \\
\$ 6 \\
-86\end{array}$ & $\begin{array}{l}610-109 L \\
10-106 G \\
710-89 C\end{array}$ & $\begin{array}{c}14.81018 .3 \\
-\end{array}$ & $\begin{array}{l}-3.510-5.2 \\
-2.10-11\end{array}$ & $\begin{array}{l}3220350 \mathrm{~L} \\
363 \pm 373 \mathrm{G} \\
193+265 \mathrm{~L}\end{array}$ \\
\hline
\end{tabular}

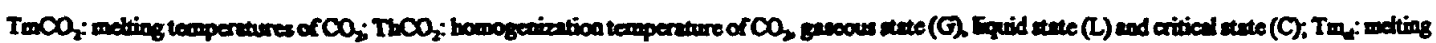

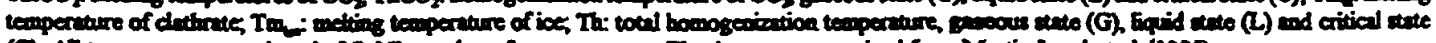

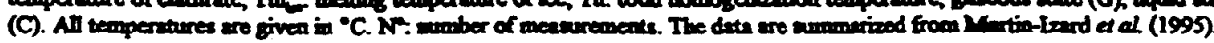


TABLE 2. RAMAN DATA AND BUTX COMPOSTION OF TFE FUTD INCLUSIONS SEI BCTED FROM THE FRANQUERA DEPOST, AND CORRESPONDING MTCROTHERMOMETRIC DATA

\begin{tabular}{|c|c|c|c|c|c|c|c|c|c|c|c|c|c|c|c|c|c|c|}
\hline \multirow[b]{2}{*}{ TYPBS } & \multirow[b]{2}{*}{$\underset{\text { mineral }}{\text { bod }}$} & \multirow[b]{2}{*}{$\mathbf{N}$} & \multicolumn{7}{|c|}{ MICROTHBRMOAETRY } & \multicolumn{4}{|c|}{ RAMAN DATA } & \multicolumn{5}{|c|}{ BULK COMPOSIIION } \\
\hline & & & $\begin{array}{l}\mathbf{V}_{\mathbf{t}} \\
\mathbf{V}_{t}\end{array}$ & $T$ mon & Those & Then & Tm & $\mathrm{Tm}$ & $\mathbf{n}$ & $\infty_{2}$ & CA. & $\mathbf{N}_{\mathbf{2}}$ & ov & $x_{n=0}$ & $x_{\infty}$ & $x_{0=0}$ & $x_{\infty}$ & $x_{\text {nea }}$ \\
\hline Typo-1 & phentite & $\begin{array}{l}\text { Fo-1 } \\
\text { Fo-2 }\end{array}$ & $\begin{array}{l}60 \\
60\end{array}$ & $=$ & : & $\begin{array}{c}110.4 \mathrm{G} \\
99.5 \mathrm{G}\end{array}$ & $\begin{array}{c}24 \\
21.7\end{array}$ & 4 & $\begin{array}{l}3710 \\
3700\end{array}$ & 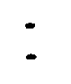 & $\begin{array}{l}80.5 \\
85.2\end{array}$ & $\begin{array}{l}19.5 \\
14.8\end{array}$ & $\begin{array}{l}0.28 \\
0.23\end{array}$ & $\begin{array}{l}70.2 \\
73.8\end{array}$ & - & $\begin{array}{l}24 \\
224\end{array}$ & $\begin{array}{l}5.8 \\
3.8\end{array}$ & : \\
\hline Typo-1 & ements & $\begin{array}{l}\text { Bcb-2 } \\
\text { Bcb-1 }\end{array}$ & $\begin{array}{l}50 \\
50\end{array}$ & - & : & $\begin{array}{l}-91 \mathrm{~L} \\
-91 \mathrm{G}\end{array}$ & $\begin{array}{l}14 \\
14\end{array}$ & -5 & $\begin{array}{l}369 \mathrm{~L} \\
354 \mathrm{G}\end{array}$ & $\begin{array}{l}15.7 \\
25\end{array}$ & $\begin{array}{l}78.9 \\
90\end{array}$ & $\begin{array}{l}5.4 \\
7.5\end{array}$ & $\begin{array}{l}0.13 \\
0.12\end{array}$ & $\begin{array}{l}8.5 \\
88.3\end{array}$ & $\begin{array}{l}2.3 \\
0.4\end{array}$ & $\begin{array}{l}8.5 \\
9.5\end{array}$ & $\begin{array}{l}0.5 \\
0.8\end{array}$ & $\begin{array}{l}0.7 \\
1\end{array}$ \\
\hline Typo-2 & covenld & $\begin{array}{l}\mathrm{B} \times 3-3 \\
\mathrm{E} \times-1\end{array}$ & $\begin{array}{l}\text { so } \\
\text { so }\end{array}$ & $\begin{array}{c}-59.4 \\
-62\end{array}$ & $\begin{array}{c}10.2 \mathrm{G} \\
8 \mathrm{G}\end{array}$ & - & $\begin{array}{l}13.4 \\
13.4\end{array}$ & $\begin{array}{c}-6.5 \\
-7\end{array}$ & $\begin{array}{l}381 \mathrm{G} \\
371 \mathrm{G}\end{array}$ & $\begin{array}{c}68 \\
52.1\end{array}$ & $\begin{array}{l}19.5 \\
412\end{array}$ & $\begin{array}{r}12.5 \\
6.7\end{array}$ & $\begin{array}{l}0.18 \\
0.21\end{array}$ & $\begin{array}{l}87.5 \\
8.5\end{array}$ & $\begin{array}{l}7.5 \\
7.5\end{array}$ & $\begin{array}{l}1.6 \\
2.9\end{array}$ & $\begin{array}{l}1 \\
0.7\end{array}$ & $\begin{array}{l}2.9 \\
3\end{array}$ \\
\hline
\end{tabular}

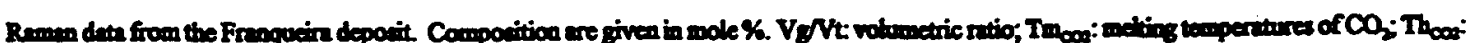

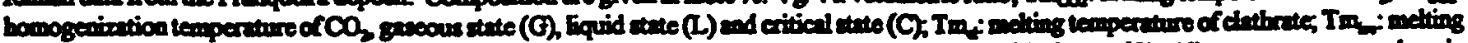

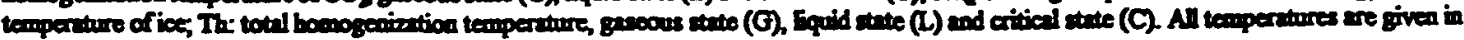
-C 8v. deniny of the voletitionich phese.
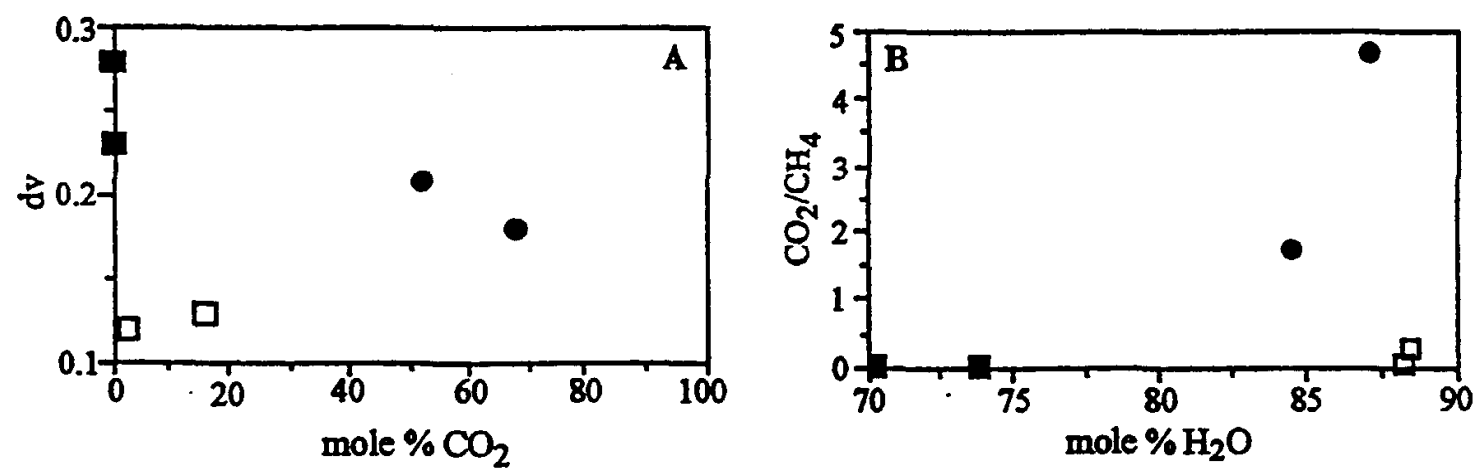

- Type-1 (phenakite)

口Typo-1 (emerald)

- Typo-2 (emerald)

Fig. 4. A. Volatile density (8v) versus $\mathrm{CO}_{2}$ mole \%. B. $\mathrm{CO}_{2}: \mathrm{CH}_{4}$ ratio versus $\mathrm{H}_{2} \mathrm{O}$ mole \%. Determined from Raman analysis of individual fluid inclusions from the Franqueira deposit.

Figure 4A shows density versus $\mathrm{CO}_{2}$ content of the volatile-rich phase for each inclusion type. It can be observed that type-1 inclusions may be divided into two groups, depending on whether they appear in phenakite or emerald. In the first case, the volatile-rich phase has a bigher density, and no $\mathrm{CO}_{2}$ is detected. But in the second case, there is $\mathrm{CO}_{2}$, and the volatile-rich phase has a lower density. The type- 2 inclusions, which only appear in the core of the emerald, reveal an increase in density and $\mathrm{CO}_{2}$ content of the volatile-rich phase in relation to type-1 inclusions of the same mineral.
Taking into account the bulk composition of both types of inclusion, the $\mathrm{CO}_{2} / \mathrm{CH}_{4}$ ratio versus $\mathrm{H}_{2} \mathrm{O}$ content (Fig. 4B) also shows two different groups in type-1 inclusions, depending on whether they appear in emerald or phenakite. Thus from type-1 fluid trapped in phenakite to type-1 fluid trapped in emerald, there is an increase in $\mathrm{H}_{2} \mathrm{O}$ at a similar $\mathrm{CO}_{2}: \mathrm{CH}_{4}$ ratio. The fluid trapped in the emerald core (type 2) has a $\mathrm{H}_{2} \mathrm{O}$ content similar to type-1 fluid in emerald but a higher $\mathrm{CO}_{2}: \mathrm{CH}_{4}$ ratio. 


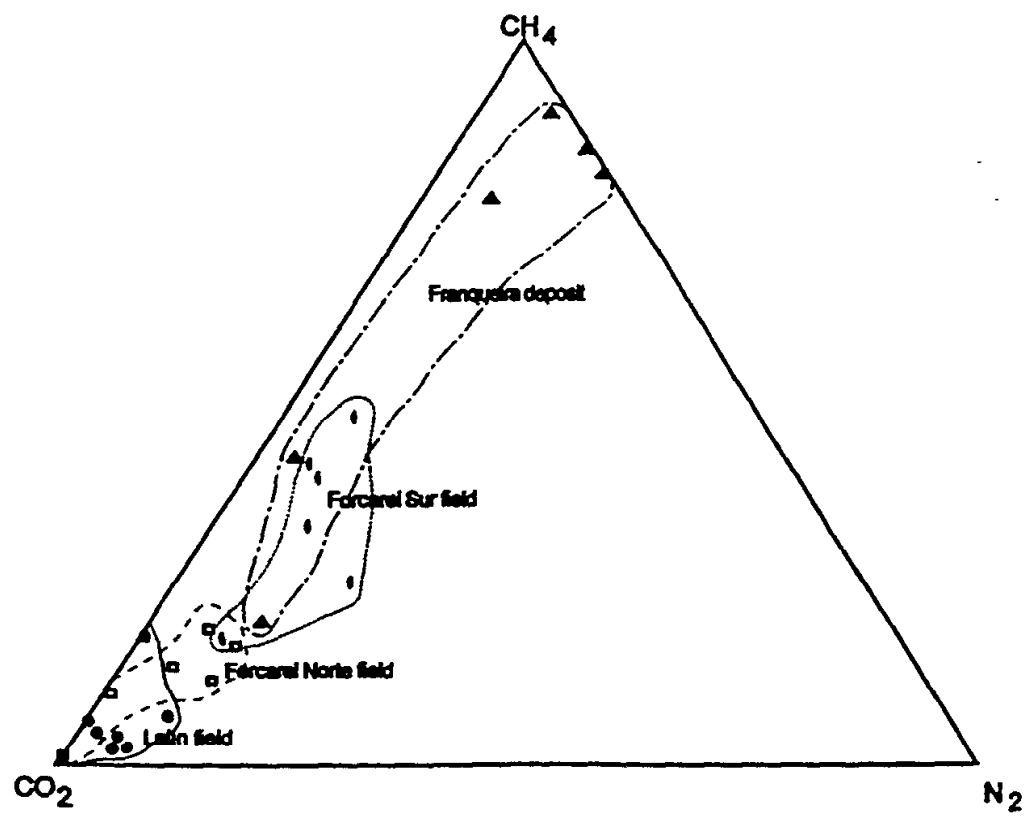

Fro. 5. $\mathrm{CO}_{2}-\mathrm{CH}_{4}-\mathrm{N}_{2}$ termary plot of the volatile-rich phase in the inclusions studied from the Franqueira deposit and each permatitic field from AEGC (Fuertes-Fuente ef al. 2000). The plot shows selected results of Ramas analyses of the aqueous-carbonic fluid of the Franqueira deposit and the three pegmatite fields from the AEGC.

The aqueous-carbonic fluids found in Franqueira can be compared with fluids from other granitic pegmatites of central Galicia (Fuertes-Fuente \& Martin-lzard 1998, Fuertes-Fuente et al 2000). These are known as AEGC pegmatites; they outcrop in three different pegmatite fields: Forcarei Sur (Fuertes-Fuente et al. 1995, Fuertes-Fuente \& Martin-Izard 1998), Forcarei Norte and Lalin (Fuertes-Fuente 1996). The metasomatic fluids found (Fuettes-Fuente et al 2000) have a composition, mainly that of their volatile phase, different for each AEGC pegmatite field, as demonstrated in the $\mathrm{CO}_{2}-\mathrm{CH}_{-}-\mathrm{N}_{2}$ ternary plot (Fig. 5). Franqueira is the richest in $\mathrm{CH}_{4}$ and, in the $\mathrm{AEGC}$ pegmatites, the $\mathrm{CH}_{4}$ content of the aqueous-carbonic fluids increases from Lalin to Forcarei Sur, with an intermediate value in Forearei Norte. The Franqueira samples were extracted from metasomatic wallrock, and this fact may explain why they are richer in $\mathrm{CH}_{4}$ than the Forcarei Sur minerals in the pegmatite samples, which were extracted from minerals close to the pegmatite border (Fuertes-Fuente \& Martin-Izand 1998). The minerals of the pegmatites from Forcarei Norte and Lalin were not extracted from the border of these bodies. This fact suggests a minor CH4 content. The fact that Forcarei Norte is enriched in CH4 compared to Lalin may be due to the fact that the metasediments in which Forcarei Norte pegmatites are enclosed have graphite horizons; these are absent in the metasedimentary units in which the Lalin pegmatites were emplaced (Fuertes-Fuente et al. 1995, 2000).

\section{P-T RECONSTRUCTION}

The calculated isochores of inclusions in emeraid and phenakite from the Franqueira deposit are shown in Figure 6. The P-T evolution of the metasomatic fluids at Franqueira are discussed with reference to this figure. From these isochores, two stages of fluid circulation have been established during the metasomatic event.

The first stage is represented by trapping of type-1 fluid in phenakite at relatively high $\mathrm{P}-\mathrm{T}$ conditions. The minimum conditions of trapping are those given by the Th-Ph pair, which is $370-371^{\circ} \mathrm{C}$ and 2-2.5 kbar. Martin-lzard et al. (1995) proposed temperatures between 380 and $420^{\circ} \mathrm{C}$; we consider an average temperature of $400^{\circ} \mathrm{C}$ as the temperature closest to conditions of formation (Fig. 6). In this way, the fluid inclusions and Raman data in phenakite allow us to calculate a pressure for the first stage between 2.2 and $2.7 \mathrm{kbar}$, in agreement with the maximum of $4 \mathrm{kbar}$ and, the most probable value, 2 kbar, proposed by Martin-Izard et al. (1995) on the basis of the thermodynamic equilibrium model in the system $\mathrm{BeO}-\mathrm{Al}_{2} \mathrm{O}_{3}-\mathrm{SiO}_{2}-\mathrm{H}_{2} \mathrm{O}$ developed by Barton (1986) (Fig. 7).

Fluid-inclusion data give us temperatures of formation much lower than those corresponding to the chrysoberyl + quartz stability field (Fig. 6), close to the

$$
\text { euclase }=\text { beryl }+ \text { phenakite }+ \text { chrysoberyl }
$$




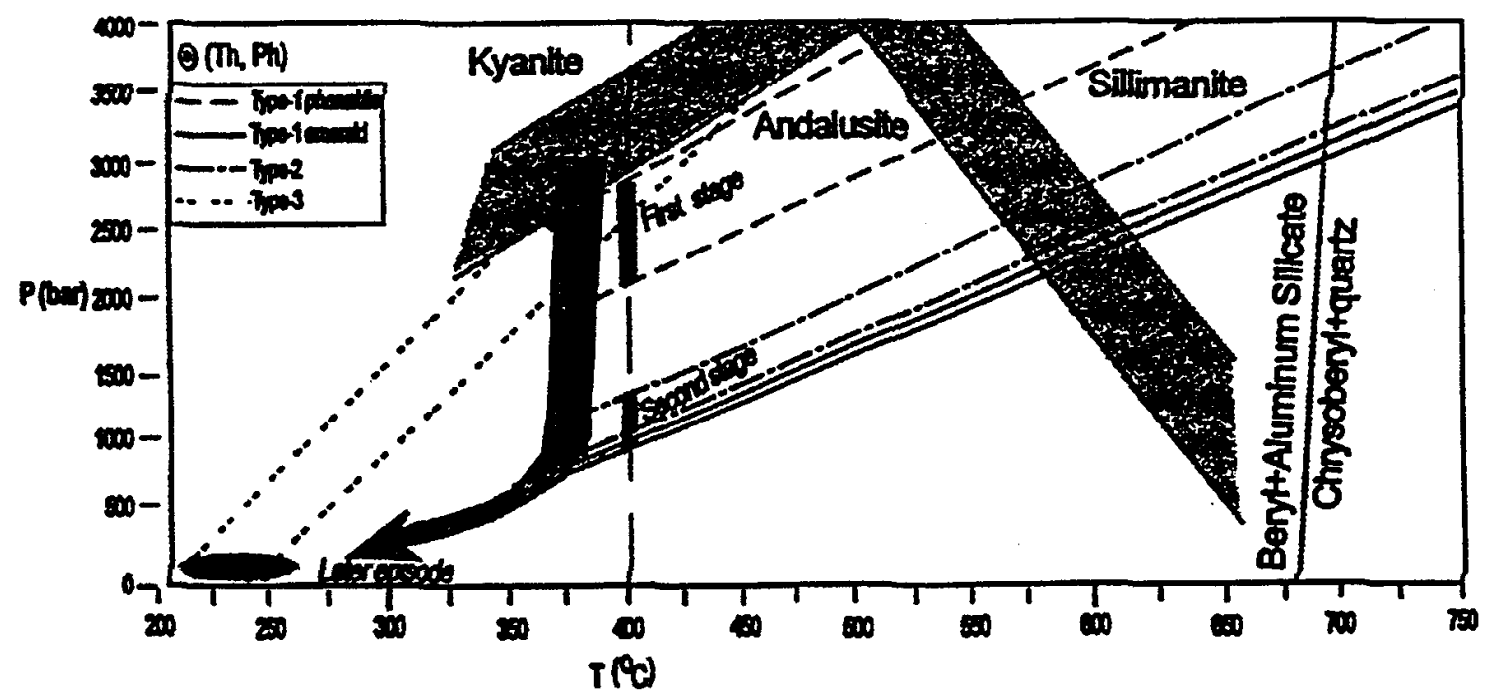

Fro. 6. P-T reconstruction, with the isochores representative of the different types of fluid inclusion in the Franqueira deposit. The dark zones are the minimum P-T conditions for the different theses of trapping of type-1 fluid inclusions in pheculate and emeraid, type-2 and type-3 inchusions. The open circles on isochores represent the homogenization temperature and pressure. The vertical dashed line represents an averige temperature $\left(400^{\circ} \mathrm{C}\right)$ from the temperature range proposed by Martio-lzard et al (1995) taking into account that the mineralization is formed by a contact metamorphic-metasomatic process.

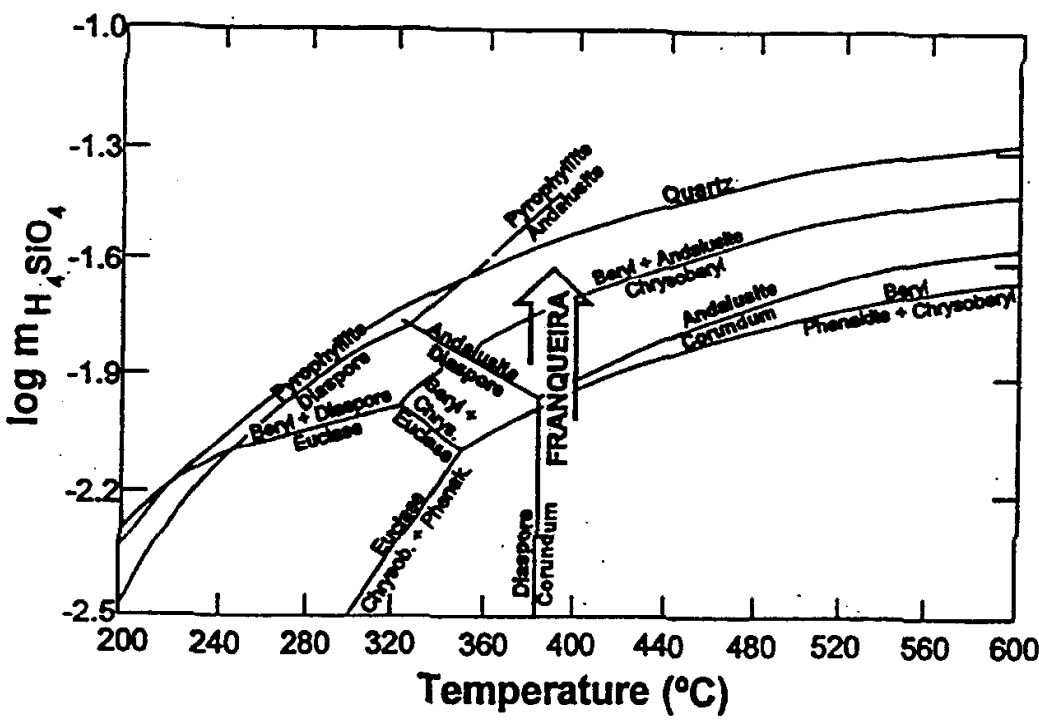

FiG. 7. Log $\mathrm{mH}_{4} \mathrm{SiO}_{4}-$ temperature projection at $P=1 \mathrm{kbar}$ and activity of beryl $=0.1$, showing a path consistent with the evolution of Be-assemblages at Franqueira (from Martin-lard et al. 1995).

join. The absence of euclase indicates a minimum range of temperatures and pressures, i.e., a $\mathrm{P}$ of $4 \mathrm{kbar}$ and a $\mathrm{T}$ ranging from $350^{\circ} \mathrm{C}$ (for $\mathrm{P}=1 \mathrm{bar}$ ) to about $450^{\circ} \mathrm{C}$ (for $P=4 \mathrm{kbar}$ ), in the stability field of andalusite.
The type-1 and type-2 fluids trapped in emerald display a lower density than type-1 fluid trapped in phenakite, yielding lower minimum pressures $(\mathrm{Ph})$, in the $0.75-1 \mathrm{kbar}$ range and a minimum temperatures $(\mathrm{Th})$ in 
the $354-381^{\circ} \mathrm{C}$ range. Taking into account the evolvtion of Be-bearing assemblages at Franqueira (MartinIzard et al 1995), we consider that the temperature did not change with respect to the first stage, around $400^{\circ} \mathrm{C}$ (Fig. 6). If so, the pressure of this second stage is around 1 kber. These data are also in agreement with the proposal by Martin-Izard et al (1995).

During the first hydrothermal stage, the most probable pressure of trapping of type-1 fluid in phenakite is around $2 \mathrm{lbar}$ and a temperature around $400^{\circ} \mathrm{C}$. This pressure probably represents a lithostatic pressure indicative of a relatively deep structural level $(7-8 \mathrm{~km})$. The type-1 and type-2 inchusions in emerald display lower densities, thos these inclusions were trapped in the range of 1 bar. Such variation conld be explained by a pressure drop from lithostatic to partially hydrostatic conditions during decompression.

The characteristics and isochores of type-3 fluid inclusions (Martin-Irard et al. 1995) suggest a later unrelated episode of hydrothermal fluid circulation at minimum trapping temperatures ranging from $160^{\circ} \mathrm{C}$ to $265^{\circ} \mathrm{C}$ and pressures below $0.5 \mathrm{kbar}$.

\section{Discussion}

The evolution of the fluid associated with the metasomatic process is as follows. Under pressures between 2 and $2.5 \mathrm{kbar}$ and a temperature close to $400^{\circ} \mathrm{C}$, a first stage is developed in which an aqueous-carbonic fluid, dominated by $\mathrm{H}_{2} \mathrm{O}$ and of very low salinity, is trapped. The fluid is composed of a volatile phase made up of methane and minor quantities of nitrogen, with an average composition of 72 mole $\% \mathrm{H}_{2} \mathrm{O}, 23.2$ mole $\% \mathrm{CH}$ and 4.8 mole $\% \mathrm{~N}_{2}$. A pressure drop produced a second stage of fluid trapping at $400^{\circ} \mathrm{C}$ and 1 lbar. During this latter stage, emerald formed from phenalite and chrysoberyl (reaction 1 and Fig. 6), thus indicating an increase in silica activity (Barton 1986). At that moment, two different fluids were simultaneously trapped by emerald: (1) an aqueous low-salinity fluid with a CHA-rich volatile phase (type-1 inclusions), and (2) a $\mathrm{CO}_{2}$-rich fluid with higher salinity (type-2 inclusions). sion:

Two possible explanations are presented for discus-

1) At the beginning of emerald crystallization, probably due to a drop in pressure during the second stage and an increase in $\mathrm{SiO}_{2}$ activity, the initial metasomatic fluid trapped in phenakite evolved into two different aqueous fluids, $\mathrm{CO}_{2}$-rich and $\mathrm{CH}_{4}$-rich, in accordance with the reaction of $\mathrm{CH}_{4}$ with $\mathrm{H}_{2} \mathrm{O}$ to form $\mathrm{CO}_{2}$ and $\mathrm{H}_{2}$ the latest of which may diffuse away. Both fluids $\left(\mathrm{CO}_{2}\right.$ rich and $\mathrm{CH}_{4}$-rich) have different densities, with the $\mathrm{CO}_{2}$-rich fluid having the higher density (Fig. 4A). This fact could explain why the volatile phase with higher density and $\mathrm{H}_{2} \mathrm{O}$ salinity was concentrated in the fluid trapped by the emerald core (type-2, $\mathrm{CO}_{2}$-rich), whereas the volatile phase with the lower density and $\mathrm{H}_{2} \mathrm{O}$ salin- ity (type-1, $\mathrm{CH}_{4}$-rich) kept on getting trapped during the remainder of the emerald growth. In this way, two immiscible fluids are trapped in the emerald core. This agrees with a growth of emerald during a stage of heterogeneous trapping in the system $\mathrm{H}_{2} \mathrm{O}-\mathrm{NaCl}-\mathrm{CH}_{4}$ $\mathrm{CO}_{2}-\mathrm{N}_{2}$, as was proposed by Martin-lzand et al (1995).

2) At the begining of emerald crystallization, a fluid (type-2) from the pegmatite body circulated through the host rock and mixed with type-1 fluid found in phenakite, from which phenakite and, probably, chrysoberyl were formed. Note that several authors have observed that fluids in pegmatitic systems are generally dominated by $\mathrm{CO}_{2}$ and $\mathrm{H}_{2} \mathrm{O}$ : London (1986), Thomss \& Spooner (1988), Konnerup-Madsen \& Rose-Hansen. (1982), and Fuertes-Fuente et al. (2000) So, the methane becomes more diluted with $\mathrm{CO}_{2}$, and there is an enrichment in $\mathrm{H}_{2} \mathrm{O}$, the result of this mixture being the type-1 fluid, found in emerald. The aqueous-carbonic fluids from metasomatic tourmaline of the Tanco (Manitoba) pegmatite host-rock (Thomas \& Spooner 1988) have an average composition of 91 mole $\% \mathrm{H}_{2} \mathrm{O}$, 6 mole $\% \mathrm{CH}_{4}$, 1 mole $\% \mathrm{CO}_{2}$, and 2 mole $\% \mathrm{NaCl}$, which is comparable with that of type-1 fluid in emerald from Franqueira. These authors suggested that the unusual chemistry of these fluids result from mixing of a wallrock-derived $\mathrm{CH}_{4}-\mathrm{H}_{2} \mathrm{O}$ fluid, possibly of metzmorphic origin, with a fluid released from the pegmatite. At the Gravelotte mine (Nwe \& Morteani 1993), phenakite and emerald, which replaces the former mineral, occur on the flanks of a highly metasomatized albitite pegmatite body and in the biotite schist at and near its contact. Nwe \& Morteani (1993) described an carliest type-1 inclusion, found in phenakite and emerald, with low salinity ( $<6 \mathrm{wt} \% \mathrm{NaCl}$ in phenakite and $<\mathrm{wt} \% \mathrm{NaCl}$ in emerald) and up to $18 \mathrm{~mole} \% \mathrm{CH}_{4}$ and small amounts of $\mathrm{CO}_{2}$, Th between 250 and $400^{\circ} \mathrm{C}$ (Th phenakite $>$ Th enerald), a type-2 fluid inclusion found in emerald, which is variable in both $\mathrm{CH}_{1}-\mathrm{CO}_{2}$ contents and salinity ( 6 to $20 \mathrm{wt} \% \mathrm{NaCl}$ ), Th between 170 and $400^{\circ} \mathrm{C}$, and later type-3 and type-4 inclusions with up to $38 \mathrm{wt} \% \mathrm{NaCl}, \mathrm{CH},-\mathrm{CO}_{2}$-free. They indicated that the earliest fluids in type-1 inclusions in the phenakite become slighty more saline in the early emerald, rimming the phenakite, with a reduction of the $\mathrm{CH}_{4}$ content. With progressive crystalization of more emerald and formation of type- 2 inclusions, salinities increase and become more variable within individual crystals. Moreover, $\mathrm{CH}$, decreases, whereas $\mathrm{CO}_{2}$ increases. These authors explained these facts as the result of a mixture between type-1 fluids with a dense, high-salinity $\mathrm{NaCl}$ brine during this stage, causing a continous trend from type-1 to type-3 inclusions.

The fluid inclusions found in Franqueira are rather similar to those at Gravelotte; nevertheless, there are some important differences, which indicate a somewhat different evolution of the fluid. We consider that type-1 fluid, found in phenakite at Gravelotte and Franqueira, 
are quite similar, but at Franqueira they have no $\mathrm{CO}_{2}$. However, the emerald from Franqueira has two types of fluid inclusion, type-1 (emerald) and type-2 (only found in the emerald core). Neither type of fluid inclusion shows a variable range of salinity, and their homogenization temperatures lie within a narrow interval. In some cases, the type-2 Th is higher than type-1 Th and, in other cases, both Th ranges overlap each other (Table 1). Thus, at Franqueira, the main difference between the two types of fluid inclusion in emerald is the variable $\mathrm{CO}_{2}$ and $\mathrm{CH} / 4$ contents. We thus consider that a mixture with a high-salinity $\mathrm{NaCl}$ brine, as at the Gravelotte deposit, is unlikely to have taken place at Franqueira. However, a mixture between a $\mathrm{CH}-\mathrm{H}_{2} \mathrm{O}$ fluid, which wes perhaps derived from the wallrock, with a fluid released from the pegmatite, as at Tanco, seems to be more likely.

Nevertheless, the presence of the $\mathrm{H}_{2} \mathrm{O}-\mathrm{CO}_{2}\left( \pm \mathrm{CH}_{4}\right)$ inclusions in the emerald crystin core only and the $\mathrm{H}_{2} \mathrm{O}$ $\mathrm{CH}_{4}-\left( \pm \mathrm{CO}_{2}\right)$ inclusions in the whole of the emerald crystal, along with the fact that both inclusion types homogenize to vapor, liquid and in some cases the critical state, indicate that the immiscibility process is the more likely. If a $\mathrm{CO}_{2}$-rich fluid is added during emerald growth, $\mathrm{CO}_{2}$-rich inclusions should be found within the whole of the emerald crystal and should only homogenize in one way (liquid or vapor). On the other hand, in the case of an immiscibility due to the reaction proposed above, the $\mathrm{CO}_{2}$-rich inclusions should be formed when the oxidation process occurs, in other words, during the crystallization of the emerald core. Moreover, the salt content is very constant and low in all type-1 and type-2 inclusions, but it is a little high in type- 2 inclusions. Mixing of fluids probably generates fluids with different salinity and $\mathrm{CO}_{2}: \mathrm{CH}_{4}$ ratios, as is the case at Gravelotte (Nwe \& Morteani 1993). In Franqueira, the very constant salinity and $\mathrm{CO}_{2}: \mathrm{CH}_{4}$ ratios agree with an immiscibility model more than with a mixing of fluids.

Corncerning the origin of type-1 (phenakite) $\mathrm{CH}_{4}$ rich fluid, Thomas \& Spooner (1988) postulated that the wallrock-derived $\mathrm{CH}_{1}-\mathrm{H}_{2} \mathrm{O}$ thuid formed as a result of metamorphic reactions involving graphitic sediment. The $\mathrm{CH}_{4}$ content of fluid inclusions from the AEGC pegmatite fields (Fig. 5) is clearly correlated with the abundance of graphitic horizons in the host rocks and the closeness of the pegmatite samples selected to the host rock, this attesting the role of the host rocks in the geochemical signature of the fluids (Fuertes-Fuente et al. 2000). The Franqueira samples were extracted from metasomatic wallrock, whereas the samples of AEGC pegmatites were extracted from zones within the pegmatite bodies. This fact may have an influence on the richness in $\mathrm{CH}_{4}$ of the fluid inclusions at Franqueira (Fig. 5). However, graphite has not been reported from the pegmatite's host-rock at Franqueira nor at Gravelotte (Nwe \& Morteani 1993). Moreover, we discard the possibility of a purely metamorphic origin for type-1 (phenakite) fluid; some components of this fluid must have been derived from the pegmatite, since $\mathrm{Be}, \mathrm{Al}$ and Si are necessary for the formation of phenakite and chrysoberyl. These minerals could not have come from the host rock because beyond the metasomatic zone; it contains no phenalite. Thus we leave open the dicussion about the source of type-1 (phenakite) CH/rich fluid.

\section{ACKONOWLEDEMENTS}

This work has been financed by the CICYT, project GEO 91/1077, PB 9610555. Supported by FPI of MEC fellowship to Fuertes. We thank to the reviewers for their encouraging suggestions, which have improved significantly the content and clarity of the paper.

\section{Reperbances}

BNocere RJ. (1995): The application of a computerised and optimised cluthrate stability model to fhuid inclusion studies ECROFI, Bol. Soc Ep. Mineral 18(1), $15-17$.

(1997): Chathrates: computer programs to calculate fluid inclusion V-X properties using clathrate melting temperstures. Compuct Geasci. 23, 1-18.

Dugessy, J. \& CathernveaU, M. (1996): Improvements in elathrate modelling. 1 . The $\mathrm{H}_{2} \mathrm{O}-\mathrm{CO}_{2}$ system with various salts. Geochim Cosmochin. Acta 60, 1657-1681.

BARRERA, J.L., FARUS, P., GONZALEZ, F., MARQURNEZ, J., MARtin, L.M., Martinez, J.R. Del OlMo, A. \& De Pablo, J.G. (1989): Mapa Geológico 1:200.000 de Ourense/Verin. Memoria explicativa. Publicación Instituto Technologico Geominero de España, Madrid, Spain.

BARTon, M.D. (1986): Phase equilibria and thermodynamic properties of minerais in the $\mathrm{BeO}-\mathrm{Al}_{2} \mathrm{O}_{3}-\mathrm{SiO}_{2}-\mathrm{H}_{2} \mathrm{O}$ (BASH) system, with petrologic applications. Am. Mineral. 71, 277-300.

Bowers, T.S. Heucezson, H.C. (1983): Calculation of the thermodynamic and geochemical consequences of nonideal mixing in the system $\mathrm{H}_{2} \mathrm{O}-\mathrm{CO}_{2}-\mathrm{NaCl}$ on phase relations in geologic systems: equation of state for $\mathrm{H}_{2} \mathrm{O}-\mathrm{CO}_{2}-\mathrm{NaCl}$ fluids at high pressures and temperatures. Geochim. Cosmochim Acta 47, 1247-1275.

Brown, P.E. \& Hagemunn, S.G. (1995): Fluid inclusion data reduction and interpretation using Macflincor on the Macintosh. ECROFI, Bol Soc. Esp. Mineral. 18(1), 32-33.

CAPDevila, R. \& Vuletre, P. (1970): Estimation radiometrique de l'ige de la deuxitume phase tectonique hercynienne en Galice moyenne (Nord-Ouest de l'Espagne). C.R. Acad Sci. Paris 270, Sér. D, 2527-2530.

DALLEYER, R.D., MARTtNez CATALAN, J.R, ARenas, R., GR lbarouchi, J.I., Gutierrez- Alonso, G., Farias, P., BASTIDA, F. \& ALLER, J.(1997) Diachronous Variscan tectonothermal activity in the NW Iberian Massif: evidence

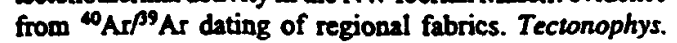
277, 307-337. 
Dusessy, J. (1984): Simulation des Equilibres chimiques dans le systitme $\mathrm{C}-\mathrm{O}-\mathrm{H}$. Constquences mithodologiques pour les inctusions fluides. Bull. Minteral. 107, 155-168.

Poty, B. \& Rancosa, C. (1989): Advences in the C-O-H-NS fluid geochemiztry besed on micro-Raman epectroscopic anslyais of fluid inciusions. Eur. J. Mineral 1, 517-534.

TrifrY, R \& CANuLs, M. (1992): Modelling of phase equilibria involving mixed gas clathrates; spplication to the determination of molar volume of the vapor phase and alinity of the aquecoss solution in fluid inchsions. Eur. J. Mineral 4, 873-884.

Farias, P., Gallasteoul, G., Gonzalez Lodetro, F., Marquitez, J., Mantth Parra, L.M., MartinezCataldA, J.R. De Pablo Macia, J.G. \& Rodrtourz FereviNoez, L.R (1987) Aportuciones al conocimiento de In litoestratigrafia y estruetura de Galicia Central. Mem. Fac. Cienc. Univ. Porto 1, 411-431.

Farsuna, A.E (1929): Geochemische Migration der Elemente. III. Smaragdgruben im Uralgebirge. Abh i praktischen Geologie u Bergwirtschuff 1, 74-116.

FUERTES-FUENTE, M. (1996): Las pegmatitas del área de LalinForcarei (Galicia) y las mineralizaciones de elementos escasos asociados. Ph.D. thesis, Univ. of Oviedo, Oviedo, Spain.

\& MARTN-IZARD, A. (1998): The Forcarei Sur rare element ( $\mathrm{Sa}, \mathrm{Ta}, \mathrm{Nb}, \mathrm{Li}, \mathrm{Be}, \mathrm{Rb}$ and $\mathrm{P}$ ) pegmatite field and its ussociated mineralization, Galicia, Spain. Can. Mineral. 36, 303-325.

BORON, M.A. \& MANOAS, J. (2000): Fiuid evolution of rere-element and muscovite granitic pegmatites from central Galicia, NW Spain. Mineral Depasita 35, 332-345.

\& MorpnRas, D. (1995): The Forcarei Sur zoned pegmatitic field, Galicia, northwestern Spain. In Mineral Deposit (J. Palava, B. Kribek \& K. Hik, eds.). Balkema, Rotterdam, The Netheriands (439-442).

Gurlan, G., Chenletz, A., Znomerenanm, I.L., RiberroALThOff, A.M., FranKCE-LANord, C. \& FERAUd, G. (1997) Les gisements d'emeraude du Brésil: genise et typologie. Chron. Recherche Geol. Miniere 526, 17-61.

JACOBS, G.K \& KeRricK, D.M. (1981): Methane: an equation of state with application to the ternary system $\mathrm{H}_{2} \mathrm{O}-\mathrm{CO}_{2}$ CH4. Geochim. Cosmochim Acta 45, 607-614.

KerRrck, D.M. \& JACOBS, G.K. (1981): A modified RedlichKwong equation for $\mathrm{H}_{2} \mathrm{O}, \mathrm{CO}_{2}$ and $\mathrm{H}_{2} \mathrm{O}-\mathrm{CO}_{2}$ mixtures at elevated pressures and temperatures. Am. J. Sci. 281, 735. 767.

Konnerup-MAdsen, J. \& Rose-HANSEN, J. (1982): Volatiles associated with alkaline igneous rift activity: fluid inclusions in the Mimaussag intrusion and the Gardar granitic compiexes (south Greenland). Chem Geol. 37, 79-93.
LAzancra, P. (1985): Empirical Metallogeny: Depositional Environments, Lithological Associations and Local Metallic Ores. 1. Phanerozoic Environments, Associations and Deposits. Elsevier, Amsterdam, The Netheriands.

Lonoow, D. (1986): Magmetic-hydrothermal trassition in the Troco rure element pegmatite: evidence from fluid incluvions and phase equilibrium experiments. Am Mineral. 71, 376-395.

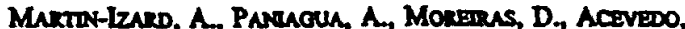
R.D. \& MAross-PAscunL, C. (1995): Metnsomation at \& granitic pegmatite - dunite contact in Oalicis: the Frroquein occurence of chryzoberyl (alexemdrite), emerald, and phenakite. Can. Mineral. 33, 775-792. (1990):

Metusomatism at a grevitic pegmitite - dunite contact in Galicir: the Frangueirn occurrence of chrysoberyl (alexsndrite), emerald, and phenakite: reply. Can. Mineral. 34, 1332-1336.

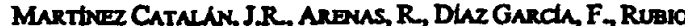
PAscuns, F J., Abath, J. \& MArouthez, J. (1996): Variscan exhumetion of a wabducted Paleosoic continental margin: the besal units of the Ondenes Complex, Galicin, NW Spain. Tectonics 15, 106-121.

MATTE, P.H. (1968): La structure de la virgation hercynieane de Galicin (Espagne). Geol. Alpine 44, 157-280.

MONTERRUBIo, S. (1991): Mineralizaciones asociadas a racas ultrabdsicas en el hercinico espariol. Ph.D. thesis, Univ. Complutense de Madrid, Madrid, Spain.

NWE, Y.Y. \& MORTEANI, G. (1993): Fluid evolution in the $\mathrm{H}_{2} \mathrm{O}-\mathrm{CH}-\mathrm{CO}_{2}-\mathrm{NaCl}$ system during cmerald mineralization at Grevelotte, Murchison Greenstone Belt, portheast Transval, South Africa. Geochim Casmochim Acte 57, 89-103.

POTTER, R.W., II \& BRown, D.L. (1977): The volumetric propexties of aqueous sodium chloride solutions from $0^{\circ}$ to $500^{\circ} \mathrm{C}$ at pressures up to 2000 bars based on a regression of available dath in the literature. U.S. GeoL Surv., Bull. 1421C, $1-36$.

C.YMNE, M.A. \& BRown, D.L. (1978): Freezing point depression of aqueous sodium chloride solutions. Econ. Geol. 73, 284-285.

POTY, B., LeroY, J. \& JACrimowncz, L. (1976): Un nouvel appareil pour la mesure des temptratures sous le microscope; l'installation de microthermometrie Chaixmeca. Bull Soc. Fr. Minéral. Cristallogr. 99, 182-186.

PrIEM, HN A \& DeN TEx E (1984) Tracing crustal evolution in the NW Iberian Peninsula through the $\mathrm{Pb}-\mathrm{Sr}$ and $\mathrm{U}-\mathrm{Pb}$ systematics of Paleozoic granitoids: a review. Phys. Earth Planet Int. 35, 121-130.

ROEDDER, E. (1984): Fluid inclusions. Rev. Mineral. 12. 
Serrano Panto, M., Casouet, C, ibarrola E., Corretoe, L.G. \& Portuanl Ferredru, M. (1987): Sintese geocronológica dos granitoides do Macizo Hesperico. In Geologla de los granitoides y rocas asociadas del Macizo Hesperico (F. Bea, A. Carnicero, M. Lopez-Plaza \& M.D. Rodriguez Alonso, eds.). Rueda, Madrid, Spain (69-86).

Snownuks, J. (1989): Emerald and Other Beryls. Geoscience Press, Prescott, Arizons.

SNEE, L.W. \& KAza, A.H. (1989): Origin and clastification of Pakituni and world emernid deponits. In Bmeralds of Pabistan: Geology, Gemology and Genesis (A.H. Kermi \& LW. Soec, eds.). Van Nostrand Reinhold Co., New York, N.Y. (229-230).

THEBRY, R., VIDN, J. \& Dunassy, J. (1994): Phsse equilibria modelling applied to fluid iaclasions: liquid-vapor equilibria and calculations of the molar volume in the $\mathrm{CO}_{2}$ $\mathrm{CH}_{1}-\mathrm{N}_{2}$ system. Geochim Cosmochim. Acta 58, 1073 . 1082.
Thomus, A.V. \& Srooner, E.T.C. (1988): Fluid inclusions in the system $\mathrm{H}_{2} \mathrm{O}-\mathrm{CH}-\mathrm{NaCl}-\mathrm{CO}_{2}$ from metasomatic tourmaline within the border unit of the Tanco zoned granitic pegmatite, S.E. Manitoba. Geochim. Casmochim Acta 52. 1065-1075.

VAN Carteren, P,W.C., Bopruth, N.A.I.M., HegedA, E.H., Priex, H.N.A., Den TeX, E., Verduruen, E.A.T. \& Verschure, R.H. (1979): Isotopic dating of older elements (including the Cabo Ottegal mafic-ultrimafic complex) in the Hercynian Orogen of NW Spain: manifestations of a presumed Eirty-Palecosoic mantle-plume. Chem Geol 24, 35-56.

ZHuNo, YL-GANo \& FuNTz, J.D. (1987): Determination of the bomogenization tempentares and densities of aupercritical Iluids in the system $\mathrm{N} / \mathrm{Cl}-\mathrm{KCl}-\mathrm{ClCl}_{2}-\mathrm{H}_{2} \mathrm{O}$ uxing synthetic fhid inctusions. Chem. Geol. 64, 335-350.

Received March 27, 1998, revised manuscripl accepted Sepcember 21, 2000. 